\title{
İlköğretim Matematik Öğretmen Adaylarının Geometrik Olasılık Problemlerini Çözme Süreçlerinin Analitik Düşünme Bağlamında İncelenmesi
}

\author{
Investigation of Problem Solving Processes of Preservice Elementary Mathematics Teachers \\ in Geometric Probability in the Context of Analytic Thinking
}

Avni YILDIZ ${ }^{1}$

Serdal BALTACI ${ }^{2}$

Özet: Olasılık üzerine yapılan çalışmalar incelendiğinde; tutum ve başarı, kavram yanılgıları, olasılık problemlerini çözme ve kurma boyutlarına odaklanıldığı görülmektedir. Fakat geometrik olasılık problemlerinin çözüm sürecinin ilköğretim matematik öğretmen adayları tarafindan nasıl gerçekleştiğinin halen yanıt bulamadığını söylenebilir. Üstelik bu süreç, son zamanlarda üzerinde önemle durulmaya başlanan analitik düşünme bağlamında incelenmiştir. Bu nedenle araştırmada, ilköğretim matematik öğretmen adaylarının geometrik olasılık problemlerini analitik düşünme bağlamında nasıl çözdüklerinin süreç olarak incelenmesi amaçlanmıştır. Özel durum çalışması yönteminin kullanıldığ 1 araştırmanın katılımcılarını, 3 öğretmen adayı oluşturmaktadır. Verilerin toplanmasında klinik mülakat kullanılmıştır. Verilerin analizinde ise nitel veri analiz yöntemlerinden faydalanılmıştır. Araştırmanın sonucunda, problemi sadece bir öğretmen adayının çözebildiği tespit edilmiştir. Fakat o öğretmen adayı, bulmuş olduğu sonucu rastlantı ile bulmadığını belirtememiştir. Ayrıca çalışmaya katılan her öğretmen adayının problemi çözerken bir algoritma izledikleri, problemin çözümüne yeterince zaman harcadıkları ve tahmin - deneme yanılma gibi yöntemleri pek kullanmadıkları tespit edilmiştir.

Anahtar Kelimeler: Analitik düşünme, geometrik olasılık, ilkögretim matematik ögretmen adayları, klinik mülakat, problem çözme.

\begin{abstract}
It is seen that the studies on probability focus on attitude, achievement, misconception, solution and formation of probability problems. But, it can be said that how preservice mathematics teachers solve geometric probability problems has not been answered yet. This process is to be examined in the context of analytic thinking which has been emphasized recently. Therefore, this study aims to examine how preservice mathematics teachers solve geometric probability problems in the context of analytic thinking. Participants of this case study are composed of 3 preservice teachers. Clinical interviews were carried out while collecting data. Qualitative data analysis methods were used in analyzing the research data. The results of this research indicated that only one preservice teacher succeeded in solving the problem. But the preservice teacher could not prove that she did not solve the problem by chance. On the other hand, all of the preservice teachers followed an algorithm in solving the given problem, spent some time in order to solve the problem gradually, and avoided using such methods as estimation - trial and error.
\end{abstract}

Key Words: Analytical thinking, geometric probability, elementary preservice mathematics teachers, clinical interview, problem solving.

\footnotetext{
${ }^{1}$ Yrd. Doç. Dr., Bülent Ecevit Üniversitesi Ereğli Eğitim Fakültesi, İlköğretim Matematik Öğretmenliği Bölümü, yildiz.avni@gmail.com, avniyildiz@beun.edu.tr

${ }^{2}$ Yazışmalardan Sorumlu Yazar. Yrd. Doç. Dr., Ahi Evran Üniversitesi, İlköğretim Matematik Öğretmenliği Bölümü, serdalbaltaci@gmail.com, sbaltaci@ahievran.edu.tr
} 


\section{Giriş}

Olasılık, günlük hayatta sıklıkla kullandığımız kavramlar arasındadır. Nitekim Kazak (2010) da olasılığı, günlük yaşamımız esnasında belirsizlik durumlarıyla karşılaştığımızda karar verme sürecinde yaygın olarak kullandığımız kavramlar arasında belirtmiştir (Kazak, 2010). Diğer taraftan çeşitli bilim dalları için de olasılık, önemli bir yer teşkil etmektedir (Bulut, 1994). Fakat olasılık, hem öğretmenler hem de öğrenciler açısından en problemli konuların başında gelmektedir (Batanero \& Serrano, 1999; Bulut, 1994; Bulut, Ekici ve İşeri, 1999; Dooren, Bock, Depaepe, Janssens \& Veschaffel, 2003; Kafoussi, 2004; Toluk, 1994; Y1ldız ve Baltac1, 2015). Matematik öğretmenlerinin büyük bir çoğunluğunun olasılık konusunun öğretiminde gerekli olan bilgi ve beceriye sahip olmadığı araştırmalarla ortaya koyulmuştur (Toluk, 1994; Tunç, 2006).

Öğrenciler, genellikle olasılık ile ilgili sorulara verdikleri doğru cevapların nedenlerini açıklayamamaktadırlar (Çelik ve Güneş, 2007). Fichbein ve Schnarch (1997) da öğrencilerin olasılık kavramlarını anlamlandırma sürecinde mantıktan çok önsezilerini kullandıklarını, bu sebepten dolayı güçlük çektiklerini belirtmiştir. Olasılık konusunun anlaşılmasındaki güçlüğün nedenleri arasında ise öğrencilerin büyük bir çoğunluğunun konuyu anlamak yerine formülü ezberlemeye çalışmaları, soruları anlamamaları, olasılıkla ilgili kavramlara ilişkin olumsuz bir tutum geliştirmeleri ve uygun öğretim materyallerini kullanamamalarının olduğu görülmüştür (Bulut, Ekici ve İşeri, 1999; O’Connell, 1999).

Altun (2008), sürekli çoklukların (uzunluk, alan, hacim vb.) kullanılarak olasılığın hesaplanabileceğini belirterek bir alanın, içinde bulunduğu bir başka alana oranının o alana ilişkin olasılığı vereceğini ifade etmiş ve aşağıdaki örnekleri vererek bu tür olasılık hesaplarında geometriden yararlanıldığı için bunlara geometrik olasılık denileceğini vurgulamıştır. Örneğin iki halkalı hedef tahtasına isabet eden atışları göz önüne alalım. Iç̧teki alanın vurulması olasılı̆̆l, içteki halkanın alanının dıştakinin alanına oranına eşittir. Ĕğer bir karenin içinde bir daire düşünülecek olursa dairenin vurulması olasıllğgl, yine aynı yaklaşımla dairenin alanının karenin alanına oranı şeklinde hesaplanabilir. Fakat ülkemizdeki geometri öğretimi incelendiğinde daha çok bir takım sembol ve rakamların arka arkaya sıralandığı ve öğrencilerin anlamlandıramadıkları bir yapının olduğu görülmektedir (Güven, 2002). Bu nedenle geometrik olasılık problemlerini, ilköğretim matematik öğretmen adaylarının çözme süreçleri incelenmesi gereken bir durum haline gelmiştir. Bu süreçte öğretmen adaylarının düşünme stillerinin de belirlenmesi önemlidir. Çünkü yukarıda belirtilen öğrencilerin yaşadıkları bütün olumsuz durumları ortadan kaldıracak tedbirlerin ancak öğretmen adaylarının olasılık konusunu anlatırken veya problemleri çözerken düşünme stillerinin neler olduğuna yönelik tespitlerin ardından alınabileceği aşikârdır.

Dewey (2007) analitik düşünmeyi, iyi bir araba tamircisinin işini yaparken izlediği yolla açıklamıştır. Dewey (2007)'e göre tamirci, araba bozulduğunda sorun ile ilişkili olduğunu düşündüğü her bir parçanın nasıl çalıştığını göz önüne alır. Böylece tamirci, sistemin nasıl hareket edeceği konusunda yaptığı tahminin olasılığının iyi olacağını bilir. Arıol (2009) da analitik düşünme eğiliminde olan kişinin; büyük bir sorunu daha basit parçalara bölerek çözümler üretebileceğini ve asıl sorunu çözmeye çalışacağını ifade etmiştir. Ayrıca Arıol (2009) bireylerin tek bir düşünme profiline sahip olmadığını, analitik düşünen bir bireyin aynı zamanda bütüncül düşünebileceğini de belirtmiştir. Burada bütüncül düşünme ile kast edilen nesnelere parça parça değil de bir bütün olarak bakmaktır. Yani bütüncül düşünen bireyler, öncelikle resmin geneline bakma ihtiyacı hissederler ve problemi anladıktan sonra detaylara konsantre olabilirler (Hammouri, 2003). Aynı zamanda bütüncül düşünen öğrenciler, tahminde bulunabilir fakat verdikleri cevapları gerekçelendirmede sorun yaşarlar (Arıl, 2009; Dewey, 2007). Dewey (2007) bu durumdaki öğrencilerin sezgilerine, geçmiş deneyimlerine ya da doğru bir cevabın nasıl üretildiğine dair belirsiz fikirlere güvendiklerini belirtmiştir. 
Analitik düşünen bireyler ise bir problemin çözümüne ulaşmak istediğinde verilen parçaları düşünürler (Molloy ve Jones, 1998). Arıol (2009) detaylara odaklanan analitik düşünen bireylerin, ardışık ve sıralı olarak problemleri çözdüklerini ifade etmiştir. Aynı şekilde Dewey (2007) analitik düşünen öğrencilerin problemi alt problemlere ayırabileceğini, bu şekilde süreç içerisinde adım adım sonuca ulaşabileceğini ve sonuçta yapılan her bir adımı açıklayabileceğini belirtmiştir. Diğer taraftan analitik düşünen bireyler; "Verilen problemi, genel olarak anladıktan sonra ipuçları ile çözüme ulaşmaya çalışır. Bu esnada problemi çözmek için zaman harcayacağını ifade ederek çözüm sırasında bir algoritma izler. Bu süreçte tahmin, deneme gibi yöntemler ile problemi çözmeye çalışmaz. Problemi parçalara ayırır ve her bir parçayı ayrı ayrı çözerek sonuca ulaşır. Böylece problem, süreç içerisinde şekillenerek çözülür. Problemi çözdükten sonra da rastlantı ile bulmadığını belirtir ve çözümü rahatlıkla anlatır." özelliklerine sahiptir (Arıol, 2009). Bu nedenle bu düşünme türünün, olasılık konusunun öğrenimindeki zorluklar da düşünüldüğünde olasılık problemlerinin çözümüne nasıl bir zemin hazırladığı araştırılması gereken bir konu haline gelmiştir.

Olasılık üzerine yapılan çalışmalar incelendiğinde tutum ve başarı (Bulut, 1994; Bulut, Yetkin ve Kazak, 2002), kavram yanılgıları (Çelik ve Güneş, 2007; Fischbein ve Schnarch, 1997), olasılık problemlerini çözme (Bulut, Ekici ve İşeri, 1999; Munisamy ve Doraisamy, 1998; O’Connell, 1999) ve olasıllk problemlerini kurma (Yıldız ve Baltacı, 2015) boyutlarına odaklanıldığı görülmektedir. Diğer taraftan analitik ve bütüncül düşünme üzerine yapılan çalışmaların; bu düşünme stillerine sahip bireylerin problem çözme becerileri ve davranışlarının incelenmesi (Arıl, 2009; Hammouri, 2003; Umay ve Arıl, 2011) ve herhangi bir kavramın öğretiminin analitik düşünme yaklaşımı ile incelenmesi (Aksoy ve Bayazıt, 2009; Kaplan ve Öztürk, 2014) boyutlarına odaklandığı tespit edilmiştir. Oysa olasılık kavramları arasındaki ilişkilerin kurulmasında yaşanan güçlüklerden dolayı bu konunun daha fazla araştırılması gerekmektedir (Aspinwall ve Shaw, 2000; Guidelines for assessment and instruction in statistics education, 2005; Memnun, 2008; National Council of Teachers of Mathematics, 2000). Bu nedenle bu araştırmada farklı olarak 3. sinıf ilköğretim matematik öğretmen adaylarının geometrik olasılık problemlerini çözme süreçlerini, analitik düşünme bağlamında incelemek amaçlanmıştır. Bu bağlamda araştırma, hem daha önce çalışılmamış bir problem durumu olması hem de araştırma bulgularının öğretmen adaylarının ilerleyen yıllardaki eğitimlerini şekillendirmek açısından kullanılabilecek olması bakımından önem arz etmektedir. Bu kapsamda araştırmanın problemi, "3. sınıf ilköğretim matematik öğretmen adaylarının geometrik olasılık problemlerini çözme süreçleri, analitik düşünme bağlamında nasıl gerçekleşmektedir?” biçiminde belirlenmiştir.

\section{Yöntem}

$\mathrm{Bu}$ bölümde; araştırmanın yöntemi, araştırmanın katılımcıları, verilerin toplanması ve analizi hakkında bilgiler verilmiştir.

\section{Araştırmanın Yöntemi}

Özel durum çalışması yöntemiyle yürütülen araştırmalarda, belli bir grubun derinlemesine incelenmesi ve irdelenmesi esas olduğundan (Yıldırım ve Şimşek, 2008) bu araştırmada, çalışmanın doğasına uygun olduğu düşünülen özel durum çalışması yöntemi kullanılmıştır.

\section{Araştırmanın Katılımcıları}

Araştırmanın katılımcıları belirlenirken amaçlı örnekleme yöntemlerinden maksimum çeşitlilik örneklemesi kullanılmıştır. Bu yaklaşım, bilgi açısından zengin durumların seçilerek derinlemesine incelenmesi amacıyla kullanılır (Patton, 2005). Çünkü nitel çalışmalarda genellikle az sayıda kişiyle çalışılır ve kesin sonuçlara varma ya da sonuçların topluma genellenmesi kaygısı güdülmez (Yıldırım ve Şimşek, 2008). Ayrıca 
katılımcıların çok fazla olması durumunda araştırma problemini derinlemesine inceleme sürecinde zorluklar çıkacağ1 da vurgulanmıştır (Karataş, 2015; Yıldırım ve Şimşek, 2008). Bu nedenle araştırma problemine derinlemesine yanıt bulabilmek için az sayıda kişiyle çalışılmıştır.

Araştırmanın katılımcılarını bir devlet üniversitesinde, ilköğretim matematik öğretmenliği 3. sınıfa devam eden 3 öğretmen adayı oluşturmuştur. Katılımcılardan 2'si erkek ve 1'i kızdır. Diğer taraftan katılımcılar, aynı dönemde yürütülen Özel Öğretim Yöntemleri dersinde problem çözme kavramı ve problem çözme stratejileri üzerine bilgiler edinmişlerdir. Bu ders kapsamında öğretmen adaylarından farklı problem çözme stratejileri ile çözülebilecek problemler hazırlamaları istenmiştir. Bu bakımdan araştırmaya katılan tüm öğretmen adayları, problem çözme stratejileri hakkında bilgi sahibi ve problem kurma becerisine sahip bireylerdir.

Araştırmaya katılacak öğretmen adayları seçilirken, istatistik ve olasılık dersini yürüten öğretim üyesinin görüşleri ile kendini ifade etme becerisi yüksek, mülakata gönüllü ve farklı başarı düzeyine (yüksek, orta, düşük) sahip birer öğretmen adayı almaya dikkat edilmiştir. Bulgular sunulurken ise öğretmen adaylarına Şamil, Ece ve Akif takma isimleri verilmiştir. Bu bağlamda başarılı öğretmen adayından, daha düşük başarılı öğretmen adayına doğru sıralama Ece - Akif - Şamil şeklinde olmuştur.

\section{Veri Toplama Araçları}

Verilerin toplanmasında öğretmen adaylarıyla, geometrik olasılık problemlerini çözüm süreçlerinde yürütülen klinik mülakatlar kullanılmıştır. Çalışmada kullanılan geometrik olasılık problemi ise istatistik ve olasılık dersini yürüten alanında uzman öğretim üyelerinin görüşleri doğrultusunda hazırlanmıştır.

Asıl uygulamaya başlamadan önce problemin ve mülakattaki soruların etkililiğini ve eksikliklerini görebilmek için iki öğretmen adayı ile pilot çalışma yapılmıştır. Mülakatlar esnasında öğretmen adaylarına çözüm süreçlerinde yararlanmaları için trigonometrik tablo verilmiştir.

Pilot çalışmanın ardından mülakat soruları ve problem iki alan uzmanı ile birlikte kontrol edilmiş ve gerekli düzenlemeler yapıldıktan sonra uygulanmıştır. Katılımcılara geometrik olasılık ile ilgili sorulan problem “"Bir kenarl a br olan düzgün beşgen şeklindeki hedefe bir ok atılacaktır. Okun hedefi vurduğu varsayıldı̆̆ına göre bu okun hedefin köşelerinden en az b br uzaklığa isabet etmesinin olasıllğııı bulunuz. (a $\geq 2 b$ )" şeklinde oluşturulmuştur.

\section{Verilerin Analizi}

Elde edilen araştırmanın verileri, nitel veri analiz yöntemlerinden içerik analizi ile çözümlenmiştir. Bunun için uygulamaya geçilmeden önce öğrencilerle vakit geçirilmiş ve araştırmanın amacı hakkında bilgiler verilmiştir. Ardından öğrencilerle yapılan mülakatların her biri öğrencilerin izinleri alınarak dijital ses kayıt cihazı ile kaydedilmiş ve yapılan her bir görüşme yaklaşık bir saat sürmüştür. Sonrasında verilerden yapılan çıkarımlar katılımcılara sunularak yanlış veya eksik anlaşılmaların önüne geçilmeye çalışılmıştır.

Araştırmada toplanan veriler analiz edilmeden önce mülakattan elde edilen verilerin dökümü ve kontrolü yapılmıştır. Mülakat verilerini yazılı hale getirme sırasında, her bir konuşma olduğu gibi hiçbir düzeltme yapılmadan görüşmeci-görüşen sırasıyla yazılmıştır. Ardından verilerin analizine, araştırmacıların birbirinden bağımsız olarak yapmış oldukları analizlerin bir araya getirilerek tartışılmasıyla son hali verilmiştir. Bu esnada araştırmacılar arasındaki tutarlılık 0.91 olarak hesaplanmıştır. 


\section{Bulgular}

$\mathrm{Bu}$ bölümde, ilköğretim matematik öğretmen adaylarının geometrik olasılık problemlerini çözme süreçleri analitik düşünme bağlamında analiz edilmiştir. Bulgular; mülakatlardan alıntılar ve öğretmen adaylarının problemi çözerken oluşturdukları şekiller ile desteklenmiştir.

Şamil’in Problem Çözme Süreci

Şamil, problemde sayısal bir verinin olmamasından dolayı bu şekilde bir problemle daha önce karşılaşmadığını aşağıdaki gibi belirtmiştir.

Şamil: Daha önce bu şekilde bir problemle hiç karşılaşmadım. Aslında burada a ve b gibi ifadeler yerine sayısal veriler olmuş olsa idi daha kolay olabilirdi. Buradaki a ve b değerleri kafamı karıştırıyor.

Ardından Şamil, problemin çözümünde kendisine yol göstereceğini düşündüğü için ilk başta hedefi, düzgün dörtgen olarak düşüneceğini belirtmiştir. Fakat ilk başta düzgün dörtgen ile eşkenar dörtgeni birbirine karıştırmış sonrasında hatasını anlayarak düzgün dörtgenin kare olacağını anlamıştır. Şamil'in bu süreç içerisinde araştırmacı ile aralarında geçen diyalog ve oluşturmuş olduğu şekil aşağıdaki gibidir.

Şamil: Beşgen değil de düzgün dörtgenden başlasam daha iyi olacak.

A: Neden bu şekilde düşündün?

Şamil: Burada düzgün dörtgen olması daha kolay olacak gibi. Önce ona bakıp sonrasında düzgün beşgeni yapmaya çalışacă̆ım.

A: Tamam. Devam edelim o zaman.

Şamil: Düzgün dörtgen, bütün kenarları aynı paralelkenara benziyordu. Yani karşılıklı açıları toplamı 180 derece olacak.

A: Düzgün dörtgen mi?

Şamil: Evet. Ama düzgün dediği için bu açılar birbirine eşit olacak. Pardon ben eşkenar dörtgen ile karıştırdım. Bu düzgün dörtgen şu şekilde bir kare olacak.

A:Şimdi bir kare dedin. Neden bu şekilde düşündün.

Şamil: Ben yanlış düşündüm. Düzgün dörtgen deyince karıştırdım bir anda. Ama düzgün dörtgen kare demek. Probleme gelince burada bence köşelerden b birim uzaklkkta olan bu noktaları alacağız. O da 8 b birim olur dört köşede olduğu için.

A: Başka olmaz mi?

Şamil: Bence buradan bahsediyor. Sonuçta burası 4 faktöriyel eksi 8 b bölü 4 a olur.

A: Neden bu şekilde düşündün?

Şamil: Burada köşeden b birim uzaklikta olacă̆ için kenarlar üzerinde b birim uzakllğa gideceğiz. Ondan burası 8 b olur.

(A: Araştırmacı) 


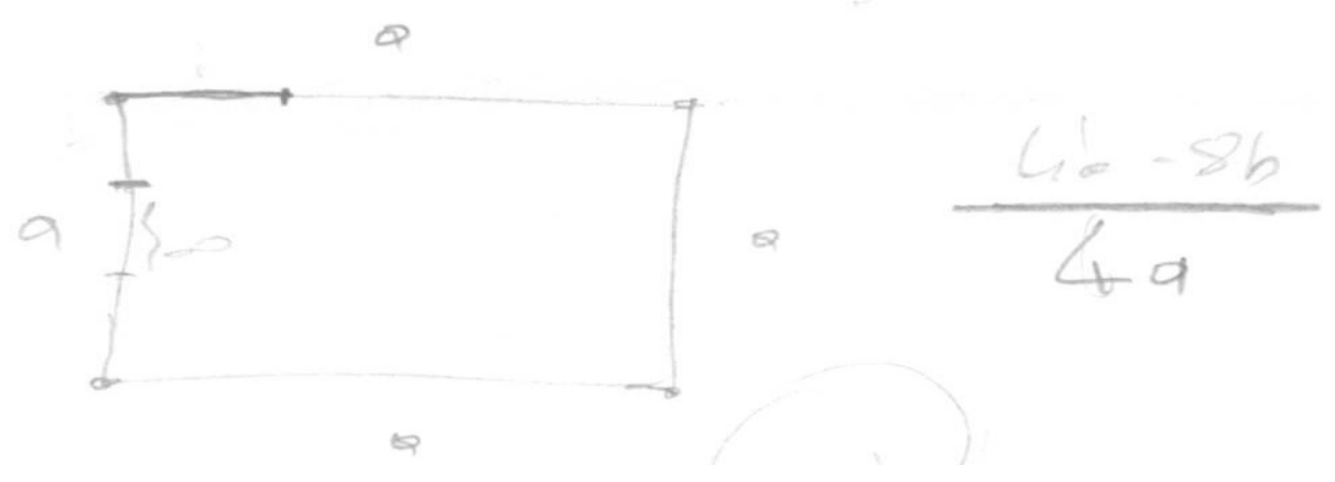

Şekil 1: Şamil'in hedefi düzgün dörtgen olarak düşündüğünde yaptı̆̆l yanllş çözüm

Şamil yukarıda görüldüğü gibi problemi çözebilmek için daha basit problem çözme stratejisini kullanmış, bunun için de kenarı a birim olan bir kare alarak köşelerinden b birim uzaklıkta kenar üzerinde olan noktaları işaretlemiştir. Fakat bu esnada Şamil, eşkenar dörtgen ile karenin özelliklerini birbirine karıştırmıştır. Ardından Şamil, analitik düşünmenin aksine bütüncül düşünerek çözümü gözünde canlandırarak çözüme başlamış ve belli bir algoritma izlemek yerine kendi fikirlerini izlemeyi tercih etmiştir. Fakat Şamil, noktaları yalnız kenar üzerinde düşünerek yanlış yapmıştır.

Sonrasında problemi yanlış anladığını fark eden Şamil, köşelerden b birim uzaklıkta olan noktaların dörtgenin iç bölgesinde de olabileceğini fark ederek doğru bir şekil çizmiş ve analitik düşünerek adım adım sonuca aşağıdaki gibi ulaşmıştır. Bu süreçte Şamil'in ifadeleri ve oluşturmuş olduğu şekil aşağıdaki gibidir.

Şamil: Aslında ben yanlış anlamışım. Çünkü burada köşelerden b birim uzaklıkta diyor. Ondan dolayı da köşeden sabit olan ve b birim uzaklikta olan noktalar bir daire dilimi oluşturmalı. Yani kare aldiğımızda köşelerdeki daire dilimleri tam bir daire yapacaktır. Onun da alanı $\pi b^{2}$ yani istenilen olasilık $\left(a^{2}-\pi b^{2}\right) / a^{2}$ olur.

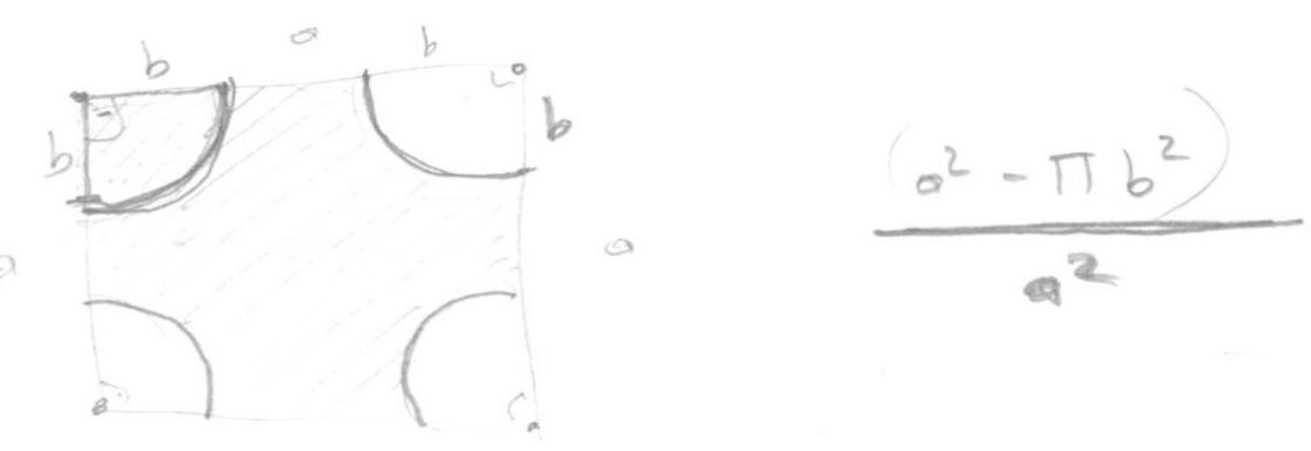

Şekil 2: Şamil'in hedefin düzgün dörtgen olması durumunda oluşturduğu doğru şekil ve çözüm.

Yukarıdaki ifadelerden de görüldüğü gibi aslında Şamil, analitik düşünerek daha basit problem çözme stratejisini kullanarak problemin çözümüne yeterince zaman harcamış ve çözüm süreç içerisinde şekillenmiştir. Sonuçta da Şamil, analitik düşünmedeki gibi problemi nasıl çözdügünü rahatlıkla anlatabilmiş ve sonucu rastlantı ile bulmadığını kanıtlamıştır. Sonrasında Şamil, hedefin düzgün dörtgen olması durumundan aldığı ipuçlarıyla hedefin düzgün beşgen olması durumunu düşünerek istenilen problemi analitik düşünmeye uygun çözeceğinin belirtilerini göstermiştir. Bunun için Şamil, ilk olarak düzgün beşgenin iç açısını belirlemeye çalışmıştır. Fakat düzgün beşgenin iç açısını düzgün altıgen ile karıştıran 
Şamil, sonrasında istenilen iç açıyı belirleyebilmiştir. Bu süreçte Şamil'in araştırmacı ile aralarındaki diyalog ve oluşturmuş olduğu şekil aşağıdaki gibidir.

Şamil: Burada yine aynı şekilde karedeki gibi köşelerden b birim olan daire dilimlerinin alanlarını bulacağım. Bunun için bir beşgenin iç açısını hesaplamak gerekir. Düzgün beşgenin bir iç açısı 60 derece idi.

A: Düzgün beşgenin bir iç açısı kaç derece dedin?

Şamil: 60 derece hocam.

A: Tamam devam edelim.

Şamil: Buna göre daire dilimlerinin alanlarını bulabilirim. Yani pi b kare 60 bölü 360 dır. Bir daire diliminin alanı. Ben bir yerde yanlış yaptım bence.

A: Bilmem. Bir dene istersen.

Şamil: Tamam işte 60 yani bir dış açısı 120 derece işte. Pardon yanlış yaptım bir iç açısını bulurken (n-2). 180 formülünü kullaniyorduk. Tamam, bence bu şekilde. O da (5-2).180=540 olur. Beşe bölersek 108 derece bir iç açısı. Tamam, şimdi oldu bence.

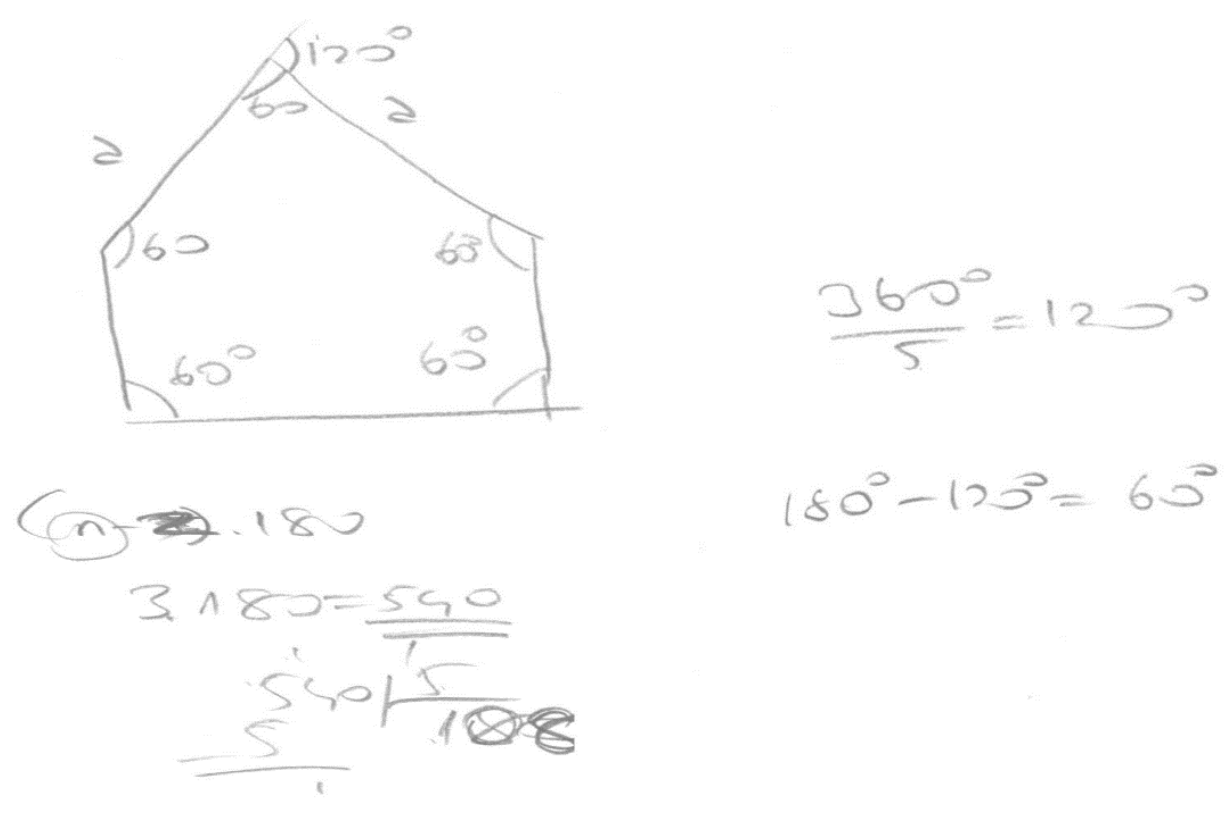

Şekil 3: Şamil’in düzgün beşgenin iç açısını doğru olarak belirleme süreci.

Görüldüğü gibi düzgün beşgenin bir iç açısını yanlış hesaplayan Şamil, süreç içerisinde yanlışını anlayarak doğru sonuca ulaşmıştır. Ardından da analitik düşünerek bir algoritma izlemiş ve köşelerden b birim uzaklıkta olan hedeflerin alanlarını belirlemeye çalışmıştır. Fakat Şamil, düzgün beşgenin alanını trigonometrik tablo elinde olmasına rağmen bulamamıştır. Şamil'in süreç içerisinde düzgün beşgenin alanını bulamadığını gösteren ifadeleri ve çizdiği şekil aşağıdaki gibidir.

Şamil: Yani yarıçapı b birim olan merkez açısı da 108 derece olan daire dilimlerinin alanını bulacağım. O da pi b kare çarpı 180 bölü 540 olur. Bu bir tanesidir. Ama düzgün beşgenin alanını nasıl bulacağım?

A: Bilmiyorum bir dene bakalım.

Şamil: Kare belli idi o kolay ama bunu bilemiyorum hocam. 


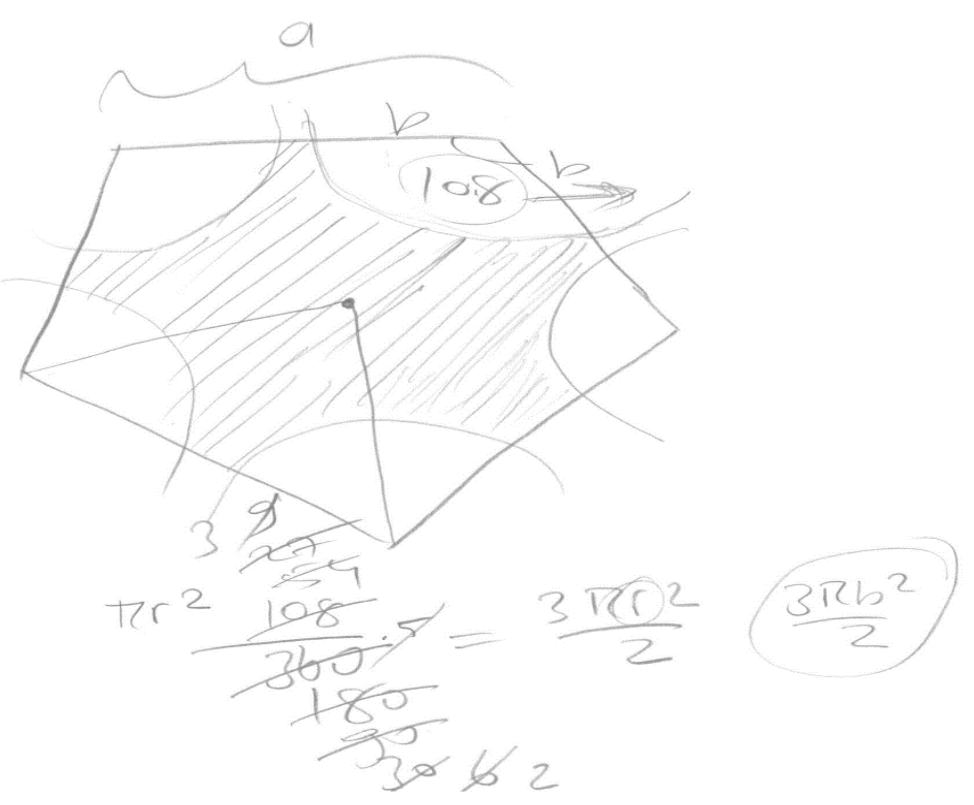

Şekil 4: Şamil ’in düzgün beşgenin alanını ifade edemeyişi.

Yukarıdaki ifadelerden görüldüğü gibi Şamil, köşelerden b birim olan daire dilimlerinin alanlarını bulabilmiş, fakat düzgün beşgenin alanını hesaplayamamıştır.

\section{Ece'nin Problem Çözme Süreci}

Problemi çözme sürecine başlarken öncelikle Ece, verilenleri ve istenenleri belirlemiştir. Fakat Ece düzgün beşgenin bir iç açısını belirlerken yanlış yapmış, sonrasında hatasını anlamıştır. Bu süreç aşağıdaki gibidir.

Ece: Ben ilk başta düzgün beşgenin bir iç açısını $120^{\circ}$ alarak yanlış yapmışım. Düzgün beşgenin bir iç açısı $108^{\circ}$ olacak. Acele etmeye gerek yok bence. Aslında problemi anladım.

Ardından Ece, analitik düşünmeye uygun olarak sırasıyla yapılacak işlemleri belirlemiştir. Bu süreçte Ece, bir iç açıyı $108^{\circ}$ olarak bularak köşelerden beş adet daire dilimi oluşacağını ve bu daire dilimlerinin $108 \mathrm{x}$ $5=540^{\circ}$ olacağını belirlemiştir. Devamında bu daire dilimlerinin alanlarını hesaplamaya çalışmıştır. İstenilen olasılığı ise Şekil 5'teki gibi göstermeye çalışmıştır. Ece'nin ifadeleri ve çizdiği şekil aşağıdaki gibidir.

Ece: Burada kisim kısim yapabiliriz.

A: Nasll yani?

Ece: Yani burada beş tane köşe var. Her bir köşenin iç açısını bulduk zaten. Bu açılara göre daire dilimlerinin her birinin alanın bulmalıyım.

A: Tamam, devam edelim o zaman.

Ece: Köşelerden b birim olan daire dilimlerinin alanı $108 \times 5$ eşittir $540^{\circ}$ lik kısma denk

gelir. Tüm alandan, bu alanlar toplamını çıkartırsak olasılığı bulmuş oluruz. 


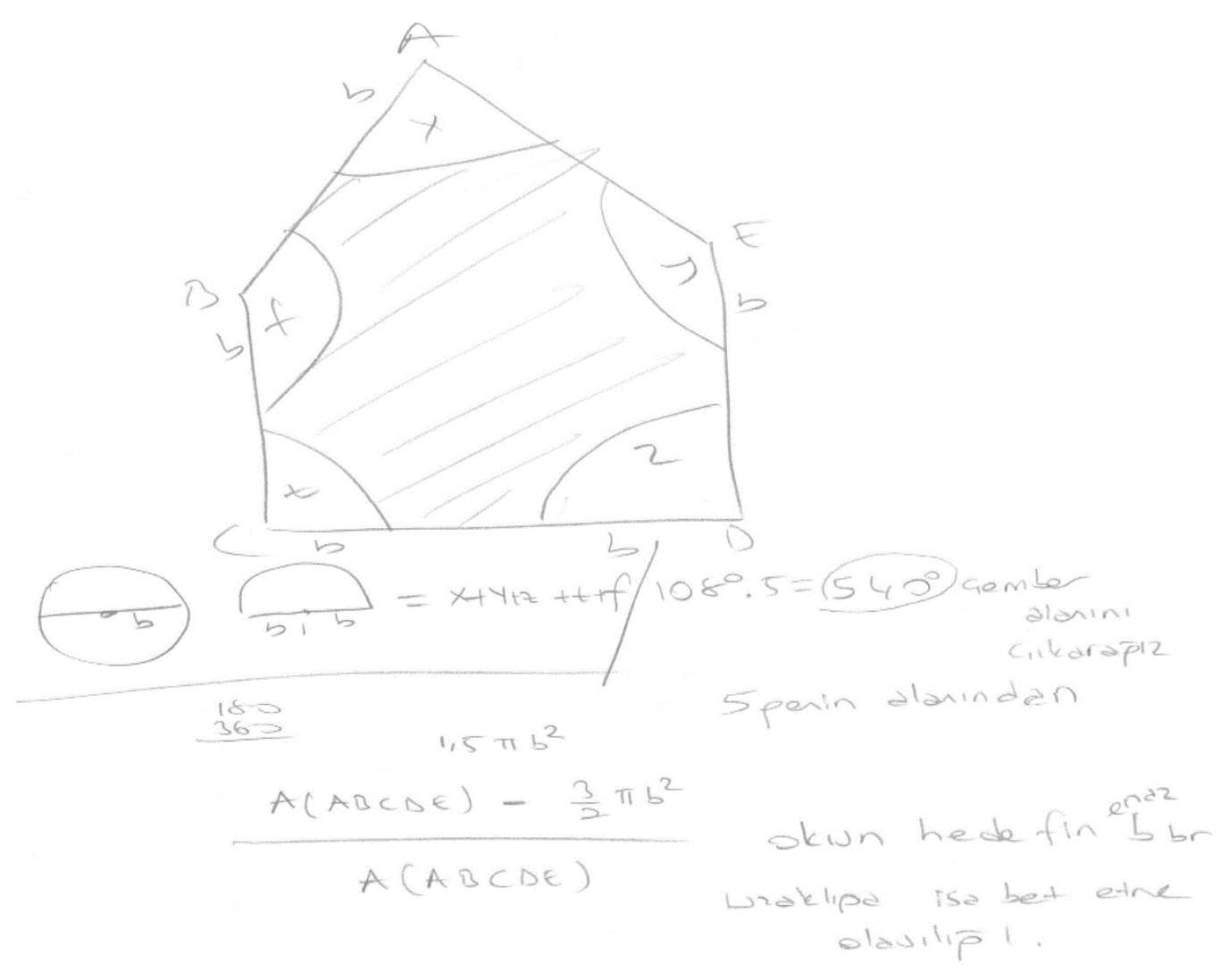

Şekil 5: Ece’nin istenilen olasılı̆̆ hesaplamaya çalışmasına ait bir kesit.

Görüldüğü gibi Ece, köşelerden b birim uzaklıkta olan daire dilimlerini teker teker belirlemiş sonrasında çıktıları birleştirerek sonuca ulaşmaya çalışmıştır. Yani Ece, analitik düşünmedeki gibi bir algoritma izlemiş ve problemde çözümü süreç içerisinde şekillendirmeye çalışmışır. Ardından Ece, istenilen olasıllı̆̆ın trigonometrik tablo kullanılarak bulunabileceğini aşağıdaki gibi belirleyebilmiştir. $\mathrm{Bu}$ süreçte Ece ile araştırmacı arasında geçen diyalog ve oluşturulan şekil aşağıdaki gibidir.

Ece: Burada düzgün beşgenin alanını bulmak için şu şekilde üçgenlere ayırırsam buralarda trigonometrik tabloyu bildiğim için sinüs alan formüllerinden üçgenlerin alanlarını bulabilirim.

A: Nasıl bulacă̆ı anlayamadım.

Ece: Yani burada üç üçgene ayırsam bu üçgenlerden iki tanesi aynı zaten. Diğerinin de kenarını cosünüs teoreminden bulur ve yine alanını bulabilirim.

A: Bir yap bakalım. 

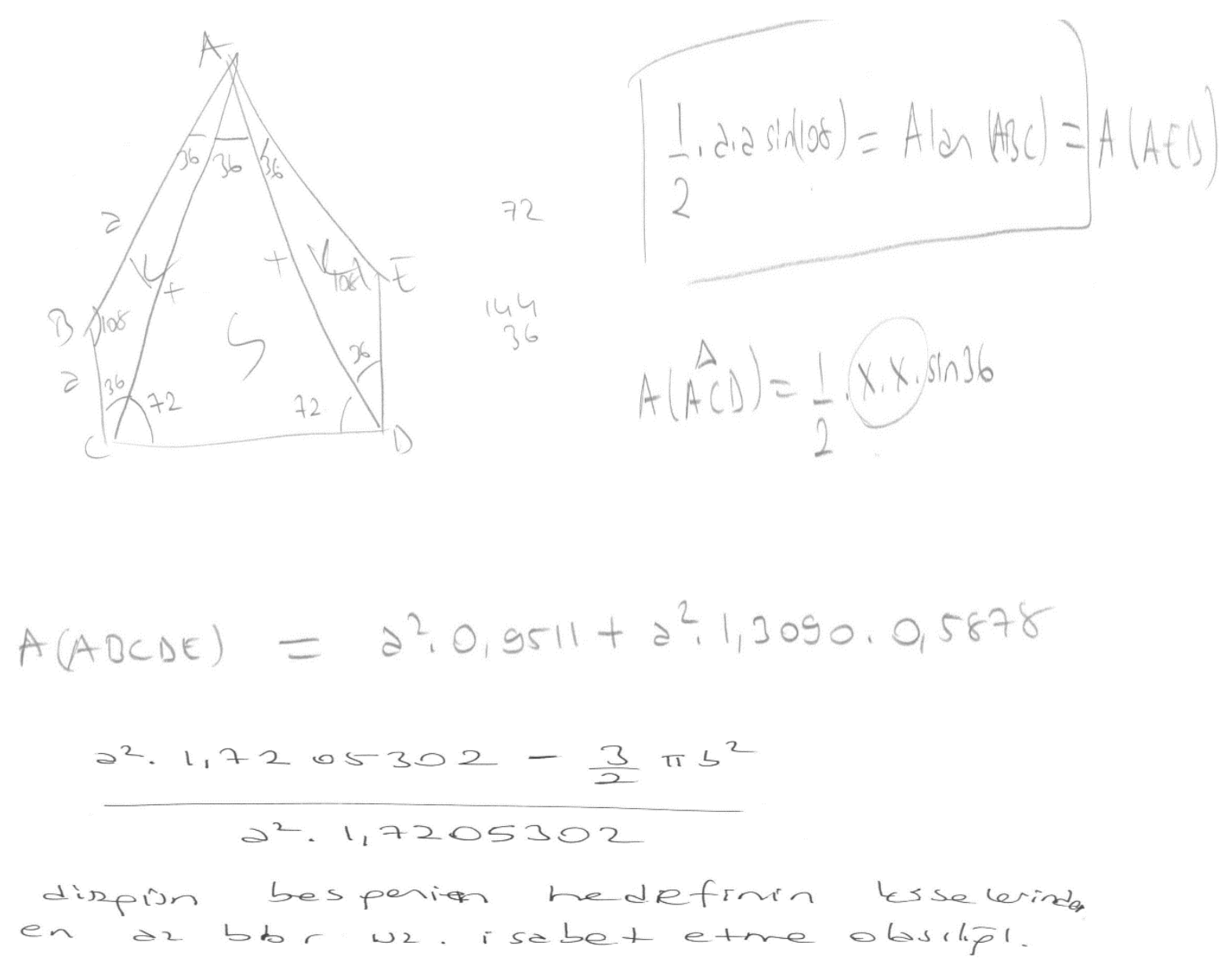

Şekil 6: Ece’nin problemi çözme süreci.

Çizilen şekiller ve araştırmacı ile aralarında geçen diyaloglardan da görüldüğü gibi Ece, analitik düşünmeye uygun olarak problemi çözerken acele etmemiştir. Bu süreçte Ece, yine analitik düşünmedeki gibi problemi nasıl çözdüğünü rahatlıkla aşağıdaki gibi belirtmiştir. Ece'nin araştırmacı ile aralarında geçen diyaloğu aşağıdaki gibidir.

A: Peki, bulduğun sonucu tekrar açılkayabilir misin? Ne yaptın bütün bu süreçte?

Ece: Burada öncelikli olarak bir düzgün beşgenin bir iç açısını belirledim ve bu beş köşeye ait olan daire dilimlerinin alanlarının 540 derecelik bir alana sahip olacă̆ını belirledim. Sonra bu daire dilimlerinin alanlarını buldum.

A: Tamam devam edelim.

Ece: Sonrasında beşgenin alanını bulmaya çalıştım ama bunu bulmak biraz zor oldu. Çünkü beşgenin alanını belirlemek kare ve eşkenar üçgene göre daha zor. Sonrasında istenilen olasilı̆̆ bir şekilde buldum.

Yukarıdan görüldüğ̈̈ gibi Ece, analitik düşünmenin aksine bütüncül düşünerek bulmuş olduğu sonucu rastlantı ile bulmadığını ifade edememiştir.

Akif'in Problem Çözme Süreci 
Akif de Şamil gibi hedefi, öncelikli olarak eşkenar üçgen ve kare alacağını ifade etmiştir. Bu süreç içerisinde araştırmacı ile Akif'in aralarında geçen diyalog aşağıdaki gibidir.

A: Ne yapıyorsun şimdi?

Akif: Düşünüyorum. Çünkü burada beşgenin alanını bulmak belki zor olacak. Ama bunun yerine kare alsam daha iyi olacak sanki.

A: Neden bu şekilde düşündün?

Akif: Yani burada kare alırsam hatta eşkenar üçgen de alsam onların alanlarını daha iyi biliyorum. Mesela eşkenar üçgen ile başlayayım ben.

A: Tamam. O zaman çözmeye başlayalım.

Akif: Hem bu şekilde problemi daha iyi çözebilirim.

Yukarıdaki ifadelerden de görüldüğü gibi Akif, istenilen durumu çözebilmek için Şamil gibi daha basit problem çözme stratejisini kullanmıştır. Yani Akif, analitik düşünerek problemi çözerken acele etmeden sonucu bulacağını göstermiştir. Ardından Akif, bu süreçte analitik düşünmenin aksine bütüncül düşünerek belli bir algoritma izlemek yerine kendi fikirlerini izlemeyi tercih etmiş ve aşağıdaki gibi sonuca ulaşabilmiştir. Bu süreç içerisinde Akif'in araştırmacı ile aralarında geçen diyalog ve çizmiş olduğu şekil aşağıdaki gibidir.

Akif: İstenilen hedef taralı bölge ise üçgenin alanından daire dilimlerin alanları toplamını çıkardı̆̆ımızda taralı bölgeyi buluruz.

A: Bu taralı alan nedir?

Akif: Tarall alan istenilen hedef yeridir.

A: Tamam. Ne yapacaksin şimdi?

Akif: Şimdi burada eşkenar üçgenin alanından daire dilimlerinin alanlarını çıkartıp istenilen hedefin alanını bulacă̆ım. Sonrasında da sorulan olasılı̆̆ı tabii.

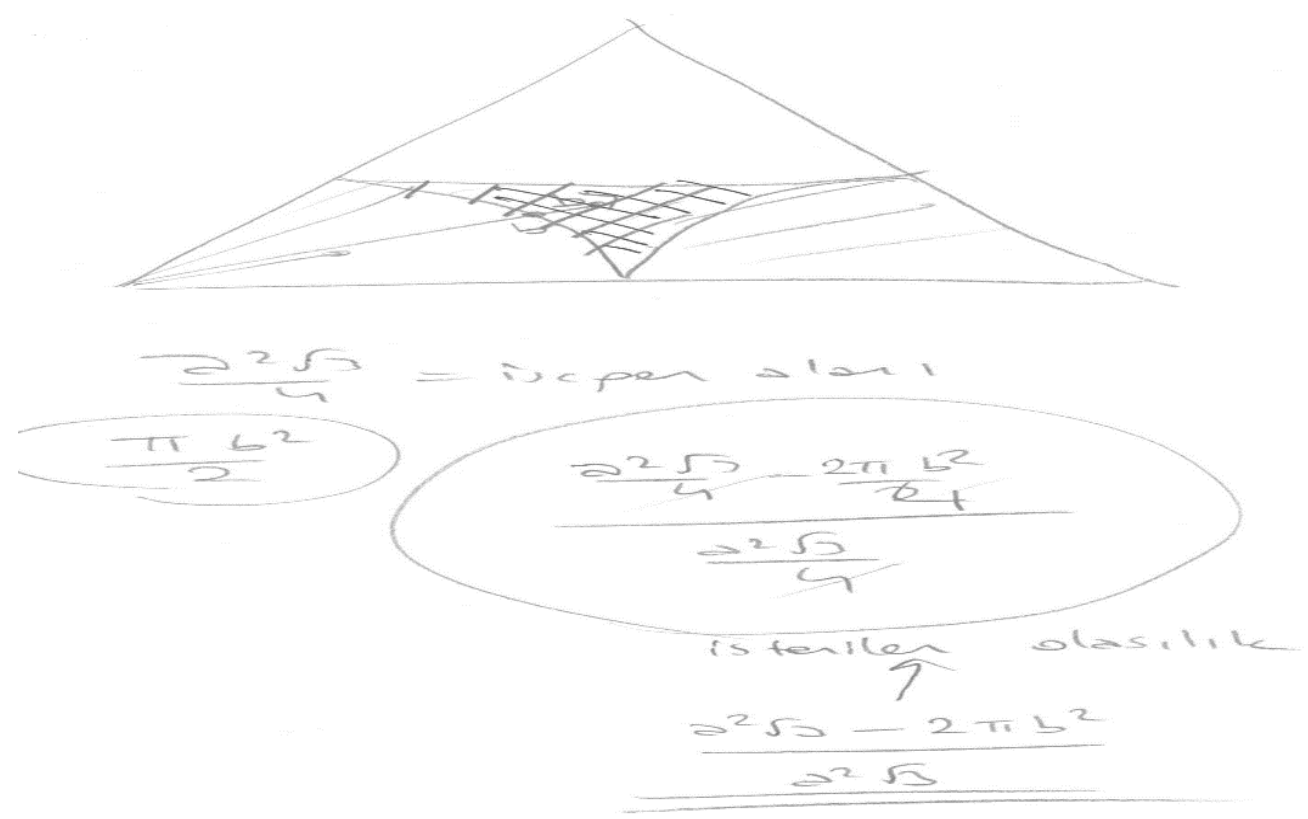

Şekil 7: Akif'in hedefin eşkenar üçgen olması durumunda çizmiş olduğu şekil ve yaptı̆̆ işlemler. 
Yukarıda görüldüğü gibi Akif, hedefin eşkenar üçgen olması durumunda istenilen olasıllğg bulmaya çalışmıştır. Bu süreçte üçgenin köşelerinden b birim uzaklıkta olan noktaları belirleyen Akif, sonrasında istenilen sonucu bulmuştur.

Sonrasında hedefin düzgün dörtgen olması durumunda olasılığı bulmaya çalışan Akif, istenilen olasıllı̆ı daha kolay bir şekilde belirleyebilmiştir. Analitik düşünerek ilk başta $a>2 b$ olacak şekilde şekil çizen Akif, $a=2 b$ olduğunda problemin çözümü için bir algoritma belirlemiş ve doğru sonucu bulabilmiştir. Bu süreci Akif' in çizmiş olduğu şekiller ve yapmış olduğu işlemler aşağıdaki gibi yansıtmaktadır.
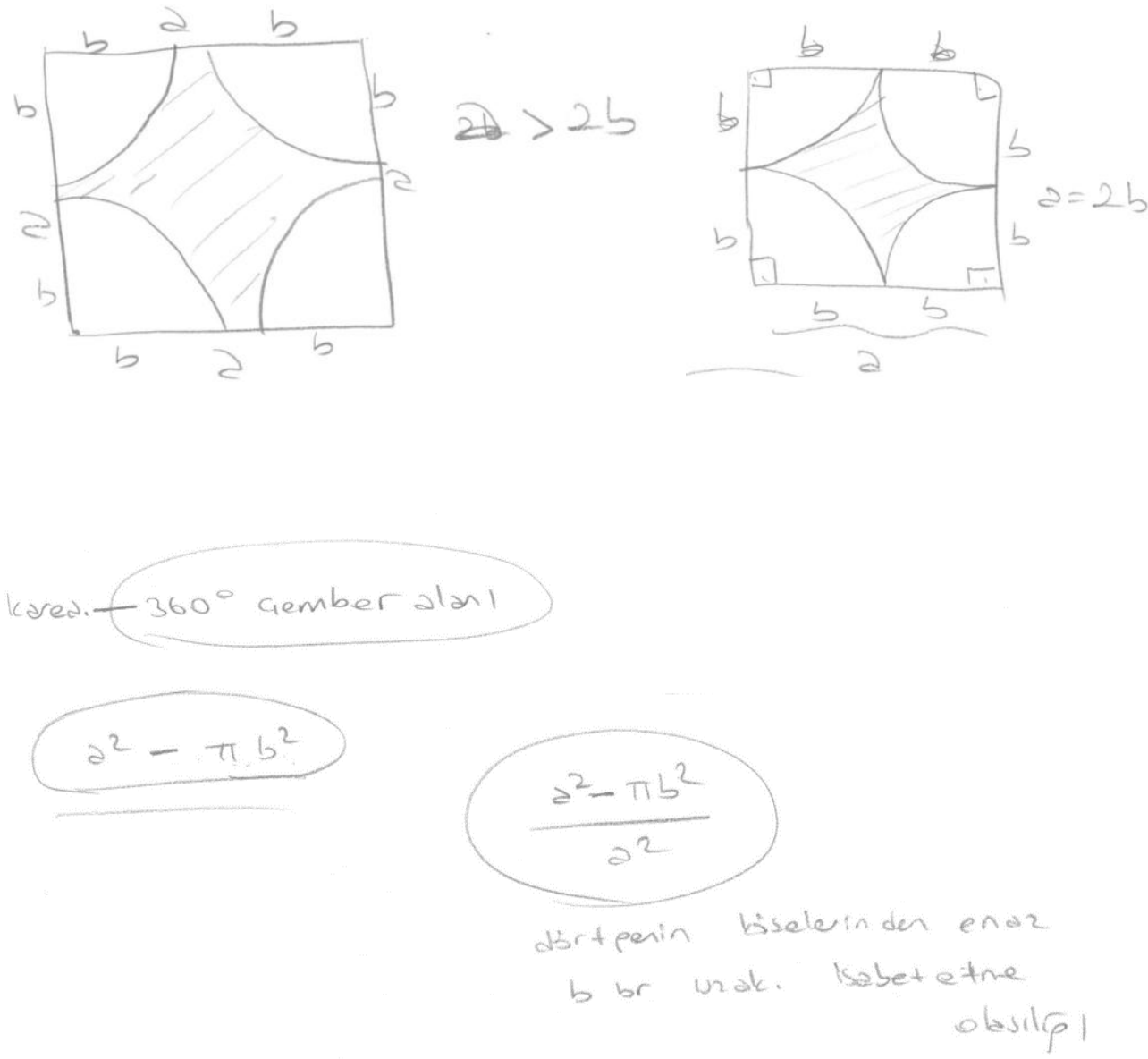

Şekil 8: Hedefin düzgün dörtgen olması durumunda Akif'in istenilen olasılığı hesaplamasına ait bir kesit.

Hedefin eşkenar üçgen ve kare olması durumlarında problemi doğru bir şekilde çözen Akif, aynı başarıyı hedefin düzgün beşgen olması durumunda gösterememiştir. Düzgün beşgenin bir iç açısını doğru olarak ifade eden Akif, alanı bulamayacağını ifade ederek verilen problemi çözmekten vazgeçmiş̧ir. Araştırmacı ile Akif arasında geçen diyalog aşağıdaki gibi bu süreci yansıtmaktadır.

Akif: Burada da aslında aynen eşkenar üçgen ve kare olması durumlarındaki gibi yapacağız. A: Nasil?

Akif: Yani hocam burada da köşelerden b birim uzaklikta olan daire dilimleri oluşacak. Beşgenin bir iç açısı 108 derece zaten.

A: Tamam. İstenilen olasılı̆̆ burada nasıl bulacağız peki?

Akif: Burada ü̧̈genlere ayırsam. Yani bu üçgenlerin alanlarını bulsam tüm beşgenin alanını bulurum bence. 


\section{A: Onları nasıl bulacaksin peki?}

Akif: Sinüs 54=0,8090; sinüs90=1;...bunlarl kullanmam gerekecek bence. Ama bunu bulmak zor. Nasıl bulacağım ki. Eşkenar üçgen ve kare kolaydı yine.

A: Devam edelim bulabilirsin bence.

Akif: Hocam bulamayacağım ben. Nasıl yapacağımı kararlaştıramadım çünkü. Aklıma bir şey gelmiyor.

Yukarıdaki ifadelerden de görüldüğü gibi aslında istenen olasılığı tam olarak ifade eden Akif, düzgün beşgenin alanını bulmada sorun yaşamış ve düzgün beşgenin alanını hesaplayamadığından sonuca ulaşamayarak çözmekten vazgeçmiştir.

\section{Tartışma ve Sonuçlar}

Şamil ve Akif, problemin çözümünde kendilerine yol göstereceğini düşündükleri için ilk başta hedefi, eşkenar üçgen veya düzgün dörtgen olarak almışlar ve doğru sonucu bulmuşlardır. Yani her ikisi de problemi çözebilmek için problemi basitleştirme stratejisini kullanmışlardır. Bu durum oldukça sevindiricidir. Çünkü bu strateji öğrencilerin hem az kullandıkları, hem de en zorlandıkları stratejiler arasındadır (Altun ve Arslan, 2006; Follmer, 2000; Yazgan, 2007; Verschaffel, De Corte, Lasure, Van Vaerenberg, Bogaerts ve Ratinckx, 1999; Yıldız, Baltacı, Kurak ve Güven, 2012). Oysa daha basit problem çözme stratejisinin önemi yapılan çoğu çalışmada vurgulanmıştır (Altun, Memnun ve Yazgan, 2007; Follmer, 2000; Vershaffel, vd., 1999; Yazgan ve Bintaş, 2005; Yazgan, 2007). Bu nedenle ilköğretim matematik ders kitaplarının içeriğinde, farklı problem çözme stratejilerinin kullanılmasını gerektiren problemlere yer verilmeli ve yer alan örnekler farklı stratejiler ile çözülmelidir.

Bütün öğretmen adaylarının problemi çözerken bir algoritma izledikleri, problemin çözümü için zaman harcadıkları fakat tahmin - deneme yanılma gibi yöntemleri pek kullanmadıkları tespit edilmiştir. Bu durum, çalışmaya katılan öğretmen adaylarının analitik düşündüklerini göstermektedir. Fakat problemi çözerken tahmin-deneme yanılmanın kullanılması önem arz etmektedir. Nitekim matematik eğitiminde tahmindeneme yanılmanın önemi gittikçe daha çok vurgulanmaktadır (Segovia ve Castro, 2009; Siegler ve Booth, 2005; Şahin, 2007; Vershaffel, vd., 1999; Y1ldı, Baltac1, Kurak ve Güven, 2012). Diğer taraftan bütün öğretmen adaylarının sergilemiş olduğu problemi çözerken bir algoritma izleme ve problemin çözümü için yeterince zaman harcama davranışı birçok araştırmaciya göre problem çözme süreçlerinde çok önemlidir (Arıol, 2009; Baltacı, Yıldız ve Güven, 2014; Elizabeth, Oaks ve Sanders, 2002; Gümüş ve Şahiner, 2015; Kılıç, 2003; Şahin, 2007; Yıldız, Baltacı, Kurak ve Güven, 2012). Çünkü ancak bu şekilde öğrenciler verilen problemi kendine göre anlamlandırabilir ve çözüm yolu bulabilir.

Akif haricinde diğer öğretmen adayları, analitik düşünmeye uygun olarak çözümlerini süreç içerisinde şekillendirmiş ve problemi nasıl çözdügünü rahatlıkla anlatabilmişlerdir. Zaten problem çözme süreci, geniş bir zihinsel süreç ve becerileri kapsayan bir eylemdir (Yenilmez ve Yaşa, 2007). Nitekim bu süreçte, yapılan eylemler üzerine düşünmek yani üstbiliş çok önemlidir. Son y1llarda problem çözme sürecinde; problemi anlama, problemin çözümüne yönelik stratejiler geliştirme, geliştirilen stratejiler ile problemi çözme ve değerlendirmenin yanında üstbiliş kavramının da üzerinde durulmasının nedenlerinden biri de budur. Çünkü bireylerin problem çözme sürecinde aldığı kararları üstbilişleri yönlendirdiğinden bireylerin üstbilişlerini geliştirmek gittikçe önem kazanmaktadır (Yıldız, 2013).

Bireyler tek bir düşünme stiline sahip değildir. Analitik düşünen birisi aynı zamanda bütüncül düşünmeye sahip olabilir ve farklı durum ve şartlarda becerilerini kullanırken bütüncül düşünmenin özelliklerini gösterebilir (Arıl, 2009). Bu araştırmada da öğretmen adayları, çözüm süreçlerinde bazen bütüncül 
düşünmenin özelliklerini göstermişlerdir. Şamil, hedefi düzgün dörtgen olarak aldığında çözümü gözünde canlandırarak çözüme başlamış ve belli bir algoritma izlemek yerine kendi fikirlerini izlemeyi tercih etmiştir. Fakat Şamil, noktaları yalnız kenar üzerinde düşünerek yanlış yapmıştır. Akif ise hedefi eşkenar üçgen olarak aldığında Şamil gibi belli bir algoritma izlemek yerine kendi fikirlerini izlemeyi tercih etmiştir. Ece de, bulduğu sonucun nedenini açıklayamamıştır.

Problem çözme sürecinde, daha düşük başarıya sahip Şamil ve Akif' in bazı temel kavramlara ilişkin kavram yanılgılarına sahip oldukları da araştırmanın ilgi çekici bulguları arasındadır. Benzer şekilde Duatepe-Paksu, İymen ve Pakmak (2013) öğretmen adaylarının, dörtgenlerin köşegenlerini açıklarken görsel ve ezbere yaklaştıklarını ifade ederek köşegen kavramını tam olarak ifade edemediklerini belirtmiştir. Yine Pickreign (2007) çalışmasında öğretmen adaylarının eşkenar dörtgen ve paralelkenarı tanımlarken eşkenar dörtgeni dik köşelere sahip olan paralelkenar olarak ifade ettikleri sonucuna ulaşmıştır. Bu çalışmada da Şamil, eşkenar dörtgen ile karenin özelliklerini ifade ederken hatalar yapmıştır. Diğer taraftan Şamil ve Ece, düzgün beşgenin bir iç açısını hesaplarken başlangıçta yanlış yapmış, sonra hatalarını fark etmişlerdir.

Şamil ve Akif düzgün beşgenin alanını trigonometrik tablo ellerinde olmasına rağmen bulamamışlar ve bu nedenle problemin sonucuna ulaşamamışlardır. Zaten olasılık problemlerini çözmek kolay bir süreç değildir (Batanero ve Serrano, 1999; Dooren, vd., 2003; Kafoussi, 2004; Munisamy ve Doraisamy, 1998; Yildiz ve Baltaci, 2015). Fichbein ve Schnarch (1997) ve O’Connell (1999) da yapmış oldukları çalışmalarında öğrencilerin olasılık problemlerini çözmeye çalışırlarken güçlük çektiklerini ve çeşitli hatalar yaptıklarını tespit etmişlerdir. Diğer taraftan problemi sadece Ece tam ve doğru olarak çözebilmiştir. Fakat Ece, problemi doğru çözmesine rağmen analitik düşünmenin aksine bütüncül düşünerek bulduğu sonucun rastlantısal olmadığını ifade edememiştir. Nitekim analitik düşünmedeki bu davranışı yalnız Şamil, hedefi düzgün dörtgen olarak aldığında yapmıştır. Stylianides, Stylianides ve Philippou (2005) da çalışmalarında öğretmen adaylarının ulaştıkları sonuçların rastlantısal olmadığını göstermede sorun yaşadıklarını görmüşlerdir. Moral1, Uğurel, Türnüklü ve Yeşildere (2006) bu süreci, matematik öğretmenlerinin yönlendirebileceğini ve sınıf ortamlarını öğrencilerin tümdengelimsel ve tümavarımsal akıl yürütme becerilerini geliştirebilecekleri şekilde düzenleyebileceklerini belirtmişlerdir. Yoo (2008) da çalışmasında "problem tabanlı öğretim" yöntemiyle öğretmen adaylarının ulaştıkları sonucu açıklayabildiklerini belirtmiştir. Aynı şekilde Baltacı (2014) da sürecin GeoGebra yazılımı ile desteklenmesiyle öğretmen adaylarının analitik geometri kavramlarını kanıtlamada başarılı olduklarını ve bu nedenle benzer ortamların oluşturulması gerektiğine vurgu yapmıştır.

Araştırma bulgularından hareketle öğretmen adaylarının, trigonometrik tablonun kullanılmasını gerektiren problemlerle meşgul edilerek bazı düzgün çokgenlerin alanlarını bulmaları sağlanmalıdır. Diğer taraftan olasılık konusuna ilişkin diğer kavramlar için de benzer uygulamaların yapılması bir araştırma konusu olarak ele alınabilir.

\section{Kaynakça}

Aspinwall, L. ve Shaw, K. L. (2000). Enriching students' mathematical intuitions with probability games and tree diagrams. Mathematics Teaching in the Middle School, 6(4), 214-220.

Aksoy, Y. ve Bayazıt, İ. (2009). Simetri kavramının öğrenim ve öğretiminde karşılaşılan zorlukların analitik bir yaklaşımla incelenmesi. E. Bingölbali ve M. F. Özmantar (Ed.) İlköğretimde karşılaşılan matematiksel zorluklar ve çözüm önerileri (1. Baskı) içinde (s. 187- 215). Ankara: Pegem Akademi Yayınevi.

Altun, M. (2008). Liselerde matematik ögretimi. Erkam matbaas1. Aktüel alfa akademi. 
Altun, M. ve Arslan, Ç. (2006). İlkööğretim öğrencilerinin problem çözme çözme stratejilerini öğrenmeleri üzerine bir çalışma, Uludă Üniversitesi Ĕgitim Fakültesi Dergisi, 19 (1), 1-21.

Altun, M., Memnun, D. S ve Yazgan, Y. (2007). Sınıf ögretmeni adaylarının rutin olmayan matematiksel problemleri çözme becerileri ve bu konudaki düşünceleri, Illköğretim Online Dergisi, 6 (1), 127.

Arıl, Ş. (2009). Matematik ögretmen adaylarının bütüncül ve analitik düşünme stillerinin matematiksel problem çözme becerilerine etkisi. Yayımlanmış Yüksek Lisans Tezi, Hacettepe Üniversitesi Sosyal Bilimler Enstitüsü, Ankara.

Baltacı, S. (2014). Dinamik matematik yazılımının geometrik yer kavramının öğretiminde kullanılmasının bağlamsal öğrenme boyutundan incelenmesi. Yayınlanmamış Doktora Tezi, Karadeniz Teknik Üniversitesi Eğitim Bilimleri Enstitüsü, Trabzon.

Baltacı, S., Yıldız, A. \& Güven, B. (2014). Knowledge types used by eighth grade gifted students while solving problems, Mathematics Education Bulletin, 28 (50), 1032-1056.

Batanero, C. \& Serrano, L. (1999). The meaning of randomness for secondary school students. Journal for Research in Mathematics Education, 30(5), 558-567.

Bulut, S. (1994). The effects of different teaching methods gender on probability achievement and attitudes toward probability, Yayınlanmamış Doktora Tezi, Ortadoğu Teknik Üniversitesi Fen Bilimleri Enstitüsü, Ankara.

Bulut, S., Ekici, C. ve İşeri, İ. A. (1999). Bazı olasılık kavramlarının öğretimi için çalışma yapraklarının geliştirilmesi. Hacettepe Üniversitesi Eğitim Fakültesi Dergisi, 15, 129-136.

Bulut, S., Yetkin, E.İ. ve Kazak, S. (2002). Matematik öğretmen adaylarının olasılık başarısı, olasılık ve matematiğe yönelik tutumlarının cinsiyete göre incelenmesi. Hacettepe Üniversitesi Eğitim Fakültesi Dergisi, 22, 21-28.

Çatlığlu, H. (2010). Matematik öğretmeni adaylartyla bağlamsal öğrenme ve öğretme deneyiminin değerlendirilmesi, Yayınlanmış Doktora Tezi, Karadeniz Teknik Üniversitesi, Trabzon.

Çelik, D. ve Güneş, G. (2007). 7. 8. ve 9. sınıf öğrencilerinin olasılık ile ilgili anlama ve kavram yanılgılarının incelenmesi. Milli Ĕgitim Dergisi. 173. 361-375.

Dewey, R. A. (2007). Psychology: An introduction. Retrieved January 13, 2015 from http://www.intropsych.com.

Dooren, W. V., Bock, D. D., Depaepe, F., Janssens, D., \& Verschaff el, L. (2003). The illusion of linearity: Expanding the evidence towards probabilistic reasoning. Educational Studies in Mathematic, 53, 113-138.

Duatepe-Paksu, A., İymen, E. ve Pakmak, G.S. (2013). Sınıf öğretmeni adaylarının dörtgenlerin köşegenleri konusundaki kavram görüntüleri, Eğitim ve Bilim, 38 (167), 162-178.

Elizabeth, M., Oaks, T. \& Sanders, T., 2002. Improving students achievement through inclusion of problem solving in the math curriculum. Master of Arts Action Research Project. Saint Xavier University and Skylight Professional Development Field-Based Master's Program. 
Fischbein, E. \& Schnarch, D. (1997). The evolution with age of probabilistic, intuitively based misconceptions, Journal of Research in Mathematics Education, 28 (1), 96-105.

Follmer, R. (2000). Reading, mathematics and problem solving: the effects of direct instruction in the development of fourth grade students' strategic reading and problem solving approaches to textbased, nonroutine mathematics problems, Unpublished PhD. Thesis, Widener University, Chester, Pennsylvania.

GAISE (2005). Guidelines for assessment and instruction in statistics education (GAISE) report: A curriculum framework for PreK-12 statistics education. The American Statistical Association (ASA). http://www.amstat.org/education/gaise/

Gümüş, Ö. F. ve Şahiner, Y. (2015). Problem çözme stratejileri öğretiminin öğretmen adaylarının problem çözümüne ilişkin düşüncelerine etkisi, İlkögretim Online, 14 (1), 323-332.

Güven, B. (2002). Dinamik geometri yazılımı Cabri ile keşfederek geometri öğrenme. Yayınlanmış yüksek lisans tezi, Karadeniz Teknik Üniversitesi, Trabzon.

Hammouri, H. A. M. (2003). An investigation of undergraduates' transformational problem solving strategies: Cognitive / metacognitive processes as predictors of holistic/analytic strategies. Assessment \& Evaluation in Higher Education, 28 (6), 571-586.

Kafoussi, S. (2004). Can kindergarten children be successfully involved in probabilistic tasks. Statistics Education Research Journal, 3(1), 29-39.

Kaplan, A. ve Öztürk, M. (2014). 2-8. sınıf öğrencilerinin simetri kavramını anlamaya yönelik düşünme yaklaşımlarının incelenmesi, Illkögretim Online, 13 (4), 1502-1515.

Karataş, Z. (2015). Sosyal bilimlerde nitel araştırma yöntemleri, Manevi Temelli Sosyal Hizmet Araştırmaları Dergisi, 1 (1). 62-80.

Kazak, S. (2010). Öğrencilerin olasılık konularındaki kavram yanılgıları ve öğrenme zorlukları. M.F. Özmantar, E.Bingölbali ve H. Akkoç (Ed.). Matematiksel kavram yanılgıları ve çözüm önerileri (s.121-147). Ankara. Pegem Akademi.

Kılıç, S. D. (2003). Illköğretim ikinci kademe son sinıf öğrencilerinin matematik derslerinde gösterdiği problem çözme yaklaşım ve becerilerinin incelenmesi, Yüksek Lisans Tezi, Dokuz Eylül Üniversitesi Eğitim Bilimleri Enstitüsü, Ortaöğretim Fen ve Matematik Alanlar Eğitimi Anabilim Dalı, İzmir.

Memnun, S.D. (2008). Olasılık kavramlarının öğrenilmesinde karşılaşılan zorluklar, bu kavramların öğrenilememe nedenleri ve çözüm önerileri. İnönü Üniversitesi Eğitim Fakültesi Dergisi. 9 (15). 89101.

Malloy, C. \& Jones, M. (1998). An investigation of African American students' mathematical problem solving. Journal for Research in Mathematics Education. 29 (2), 143-164.

Moralı, S., Uğurel, I., Türnüklü, E. ve Yeşildere, S. (2006). Matematik öğretmen adaylarının ispat yapmaya yönelik görüşleri. Kastamonu Eğitim Dergisi, 14 (1), 147-160.

Munisamy, S. \& Doraisamy, L. (1998). Levels of understanding of probability concepts among secondary school pupils. International Journal of Mathematical Education in Science and Technology, 29(1).

National Council of Teachers of Mathematics. (2000). Principles and standards for school mathematics. Reston/VA: National Council of Teachers of Mathematics Pub. 
O' Connell, A. A. (1999). Understanding the natüre of errors in probability problem-solving, Educational Research and Evaluation, 5(1), 1-21.

Patton, M. Q. (2005). Qualitative research. John Wiley \& Sons, Ltd.

Pickreign, J. (2007). Rectangles and Rhombi: How well do pre-service teachers know them? IUMPST: The Journal, Vol 1 (Content Knowledge). Retrieved February 16, 2012 from www.k12prep.math.ttu.edu.

Segovia, I. \& Castro, E. (2009). Computational and measurement estimation: Curriculum foundations and reseach carried out at the Univertsty of Granada, Mathematics didactics department. Electronic Journal of Research in Educational Psychology, 17(1), 499-536.

Siegler, R.S. \& Booth, J.L. (2005). Development of numerical estimation a review. Edited Jamie I.D. Campell. Handbook of Mathematical Cognition.

Standt, S. \& Nieuwoudt, H.D. (2003). Grade 7 teachers' and prospective teachers' content knowledge of geometry. South African Journal of Education. 23(3), 199-205.

Stylianides, A.J., Stylianedes, G.J. \& Philippou, G.N. (2005). Prospective teachers' understanding of proof: What if the truth set of an open sentence is broader than that covered by the proof? Chick, H.L.\& Vincent, J.L. (Ed.). Proceedings of the 29 th Conference of the International Group for the Psychology of Mathematics Education, 4, 241-248.

Şahin, A. A. (2007). 13-14 yaş grubu ögrencilerin problem çözme stratejilerinin belirlenmesi, Yayımlanmış Yüksek Lisans Tezi, Balıkesir Üniversitesi Fen Bilimleri Enstitüsü, Balıkesir.

Umay, A. ve Arıl, Ş. (2011). Baskın olarak bütüncül stilde düşünenlerle baskın olarak analitik stilde düşünenlerin problem çözme davranışlarının incelenmesi, Pamukkale Üniversitesi Eğitim Fakültesi Dergisi, 30, 27-37.

Toluk, Z. (1994). A study on the secondary school teachers views on the importance of mathematical knowledge and when they acquired this knowledge. Yayınlanmamış Yüksek Lisans Tezi, Orta Doğu Teknik Üniversitesi, Ankara.

Tunç, E. (2006). Özel ilköğretim okulları ile devlet okullarının 8. Sinıf ögrencilerine olasılık konusundaki bilgi ve becerileri kazandırma düzeylerinin değerlendirilmesi, Yayınlanmış Yüksek Lisans Tezi, Balıkesir Üniversitesi Fen Bilimleri Enstitüsü, Balıkesir.

Vershaffel, L., De Corte, E., Lasure, S., Vaerenbergh, Bogaerts, H. \& Ratinckx, E. (1999). Learning to solve mathematical application problems: A desing experiment with fifth graders, Mathematical Thinking and Learning, 1(3), 195-229.

Yazgan, Y. ve Bintaş, J. (2005). İlköğretim dördüncü ve besinci sınıf öğrencilerinin problem çözme stratejilerini kullanabilme düzeyleri: Bir öğretim deneyi, Hacettepe Üniversitesi Eğitim Bilimleri Dergisi, 28, 210.

Yazgan, Y. (2007). Dördüncü ve besinci sınıf öğrencilerinin rutin olmayan problem çözme stratejileriyle ilgili gözlemler, İlköğretim-Online Dergisi, 6 (2), 249.

Yenilmez, K. ve Yaşa, E. (2007). İlköğretim öğrencilerinin problem çözme üzerine bir inceleme. e-Journal of New World Sciences Academy, 2 (4).

Yıldırım, A. ve Şimşek, H. (2008). Sosyal bilimlerde nitel araştırma yöntemleri (6. Baskı). Ankara: Seçkin Yayınc1lik. 
Yıldız, A., Baltacı, S., Kurak, Y. ve Güven, B. (2012). Üstün yetenekli ve üstün yetenekli olmayan 8. sınıf öğrencilerinin problem çözme stratejilerini kullanma durumlarının incelenmesi. Uludă̆ Üniversitesi Eğitim Fakültesi Dergisi, 25 (1), 123-143.

Yıldız, A. (2013). Ders imecesinin matematik ögretmenlerinin problem çözme ortamlarında öğrencilerinin üstbilişlerini harekete geçirmeye yönelik davranışlarına etkisi, Yayınlanmamış Doktora Tezi, Karadeniz Teknik Üniversitesi Eğitim Bilimleri Enstitüsü, Trabzon.

Yıldız, A. ve Baltacı, S. (2015). İlköğretim matematik öğretmen adaylarının problem kurma etkinlikleri ile olasılığa yönelik bilgilerinin incelenmesi, Ahi Evran Üniversitesi Kırşehir Eğitim Fakültesi Dergisi (KEFAD), 16 (1), 201-213.

Yoo, S. (2008). Effects of traditional and problem-based instruction on conceptions of proof and pedagogy in undergraduates and prospective mathematics teachers, Phd Dissertation, The University of Texas, Austin.

\section{Extended Abstract}

Purpose

Probability is among the concepts we use widely in making decisions in our everyday life. It is one of the most problematic subjects, however, for both teachers and students. Why probability is difficult to understand is related to the fact that students mostly try to memorize formulations instead of comprehending them, do not understand the question, develop negative attitude towards these concepts, and do not use appropriate instruction materials. Furthermore, a great deal of mathematics teachers lack the knowledge and skills required for teaching probability. As for teaching geometry in our country, it is seen that a series of symbols and figures is compiled consecutively and there appears a structure which students cannot make sense of. How elementary preservice mathematics teachers solve questions of geometric probability has been a burning question therefore. It is obvious that the measures to resolve the afore-mentioned negative circumstances can be taken only during training of preservice teachers.

In the relevant literature, it is indicated that individuals with ability of analytic thinking "set out to solve a given problem through clues after understanding it roughly. They disintegrate the given problem and reach a solution by solving each part separately. They solve the problem by shaping and processing it. They know it will take some time to solve the problem and follow an algorithm. Upon solving the problem, they prove they have not solved it accidentally and can explicate the solution easily. They do not attempt to solve the problem by such ways like estimation or trial". Given the difficulties in learning probability, how this type of thinking contributes to solving probability problems is a matter of the study.

It is seen that the studies on probability focus on attitude, achievement, misconception, solution and formation of probability problems, whereas the studies on analytic and holistic thinking focus on examining the instruction of a concept through analytic thinking approach and the problem-solving behaviors of those who possess such thinking skills. From this point of view, it can be said that how elementary preservice mathematics teachers solve geometric probability problems has not been answered yet. This process is to be examined in the context of analytic thinking which has been emphasized recently. Because examining how geometric probability problems are solved in the frame of analytic thinking is important in terms of shaping the further education of preservice teachers. Therefore, this study aims to examine how elementary preservice mathematics teachers solve geometric probability problems in the context of analytic thinking. 
Method

Participants of this case study are composed of 3 preservice teachers, receiving education at the third grade of elemantary school mathematics teaching, who were selected with a purposeful sampling. Two of the participants are male and one is female. As it is known, qualitative studies can be carried out with a small number of participants as they are not preocccupied with the generalisation of results for the society. Moreover, in the relevant literature, the multitude of participants is stated to create difficulty in examining a research problem in detail. This study included therefore a small number of participants in order to answer the research problem in depth. While selecting the participants, we consulted with the lecturer who were conducting the courses of statistics and probability. Besides, we paid attention to select preservice teachers with a high self-expression skill, being voluntary for the interview, and with different (high, middle, low) levels of success.

Clinical interviews were carried out while collecting data. The geometric probability problem used in the study was prepared in direction with the opinions of expert lecturers who conduct the courses of statistics and probability. Prior to the application, a pilot study was carried out with two preservice teachers in order to evaluate the efficient and deficient aspects of the interview questions. During the interviews, the preservice teachers were given a trigonometric table in order that they use while solving the problems. Following the pilot study, the interview questions and the research problem were checked by two experts and applied after required corrections were done. The research participants were asked to solve the following geometric probability problem: "An arrow will be shot at a regular pentagonal target a side of which is $a$ unit. The arrow is assumed to hit the target. So, what is the probability for this arrow to hit at least $b$ unit far from the corners of the target $(a \geq 2 b)$ ?"

Qualitative data analysis methods were used in analysing the research data. Prior to the application, we spent time with the students and informed them about the goal of the research. Each of the interviews was recorded via a digital audio recorder with permission of the students. Each interview lasted nearly an hour. In order to avoid any mis- or imperfect- understanding, the participants were informed of what we inferred from the data. The interview data were checked and put on paper before analysing the total data. While putting the interview data on paper, each dialogue was written down without any correction in a respective interviewerinterviewee order. The data analysis was finalised after pooling and discussing the analyses made by the researchers independently from each other, which was necessary to ensure the validity of the research.

Results

This section includes the analysis of how elemantary preservice mathematics teachers solve gometric probability problems in the context of analytic thinking. While presenting the results, the preservice teachers were nicknamed as Şamil, Ece and Akif.

\section{Şamil's Problem Solving Process}

Şamil stated that he has not previously came accross such a problem as it does not involve any numeric data. After he said he would assume the target as a regular tetragon at first, contemplating that it would somehow lead him to the solution. But he initially confused regular tetragon with equilateral quadrangle, he subsequently noticed his mistake and came to the conclusion that regular tetragon is a square. Afterwards, he took a square with an $a$ unit side and marked the points on the side with a $b$ unit distance from the corners. Being contrary to analytic thinking, Şamil resorted to holistic thinking and started to solve the problem by visualising it. He opted to follow his own thoughts instead of a certain algorithm. He went astray, however, 
by assuming the points only on the side. He later realised that the points which are $b$ unit far from the corners could be in the interior of the quadrangle as well. He drew a proper figure then and reached the solution step by step through analytic thinking. In other words, Şamil used the strategy of solving a simpler analogous problem by leisurely spending time to solve the problem, and the solution took shape within a process. As it is the case in analytic thinking, Şamil managed to explicate how he solved the problem and demonstrated that he did not find the solution by chance. Next Şamil found a clue by assuming the target as a regular tetragon at first and thinking the real target as a regular pentagon so that he could solve the problem in accordance with analytic thinking. He therefore tried to calculate the interior angle of the regular pentagon. Even though he confused the interior angle of regular pentagon for regular hexagon at the beginnning, he eventually figured out the required interior angle. He then followed an algorithm in tandem with analytic thinking and tried to find the area of the targets with a $b$ unit distance from the corners. However, he was unable to figure out the area of the regular pentagon despite the presence of the trigonometric table.

\section{Ece's Problem Solving Process}

Before solving the problem, Ece specified what was given and what was asked in the problem. Although she miscalculated the interior angle of the regular pentagon at first, she subsequently realised her mistake and set down what mathematical operations she would do seriatim in accordance with analytic thinking. She calculated that an interior angle would be $108^{\circ}$; five circular sectors from the corners would ensue and these sectors would be $108 * 5=540^{\circ}$. She tried to calculate the areas of those sectors then. By doing so, Ece determined each sector with a $b$ unit distance from the corners and tried to reach a solution by putting the all results together. In other words, she followed an algorithm pursuant to analytic thinking and shaped the solution of the given problem in the course of time/process. Next Ece said the probability asked could be found out by using the trigonometric table. In addition, Ece explained easily how she solved the problem, which is the case with analytic thinking. However, she was unable to demonstrate whether she reached the solution by chance or not, which may comply with holistic thinking, not with analytic thinking.

\section{Akif's Problem Solving Process}

Like Şamil, Akif said that he would take the target as an equilateral triangle and a square at first. That is to say that he used the strategy of solving a simpler analogous problem to solve the given problem just as Şamil did. By doing so, Akif implied that he would think in an analytical way and reach the solution step by step. Nevertheless, he resorted to holistic thinking rather than analytic one and followed his own thoughts rather than a certain algorithm. After Akif solved the given question of probability by determining the points which were $b$ unit far from the corners of the equilateral triangle qua target. He calculated the probability in an easier way when the target was considered as a regular tetragon. Next he drew a figure for $a>2 b$ in the beginning and then determined an algorithm for $a=2 b$. Akif could eventually reach the correct result in this way. Although Akif solved the problem correctly when an equilateral triangle and a square were taken as target, he was unable to show the same success when the target was supposed to be a regular pentagon. He set forth one interior angle of the regular pentagon correctly but gave up solving the problem by saying that he could not calculate its area.

\section{Conclusion and Discussion}

Şamil and Akif assumed the target as an equilateral triangle or a regular tetragon so that it would lead them to the solution of the problem, and so did they reach the correct result. In other words, both used the strategy of solving a simpler analogous problem. This is gladsome because it is known from the relevant literature that the strategy of solving a simpler analogous problem is not only used less by students but also perceived 
as one of the most difficult strategies, whereas its importance is emphasised in a growing number of research. Teachers should therefore help students improve their problem-solving skills by asking those questions that can be solved with the strategy of solving a simpler analogous problem.

The results of this research indicated that all of the preservice teachers followed an algorithm in solving the given problem, spent some time in order to solve the problem gradually, and avoided using such methods as estimation and trial and error. This means that all of the preservice teachers think in an analytical way in terms of these criteria. Nonetheless, using the methods like estimation and trial-and-error is crucial in problem-solving. Significance of those methods in mathematical studies is increasingly emphasised as well.

Individuals have more than one thinking styles. Those who think analytically can think in a holistic way at the same time. The preservice teachers as the participants of this research also showed some of the features of holistic thinking while solving the given problems. On the other hand, it was a striking result that the preservice teachers with lower levels of success still misapprehend some basic concepts. Several other studies support this result.

Only one preservice teacher succeeded in solving the problem. But the preservice teacher could not prove that she did not solve the problem by chance, however. Another preservice teacher who assumed the target as a regular tetragon proved that he did not solve the problem by chance, which is important in terms of analytic thinking. 